\begin{tabular}{|c|l|}
\hline Title & Phylogenetic Comparison of Endosymbionts with Their Host Ants Based on Molecular Evidence \\
\hline Author(s) & Sameshima, Shinya; Hasegawa, Eisuke; Kitade, Osamu; Minaka, Nobuhiro; Matsumoto, Tadao \\
\hline Citation & $\begin{array}{l}\text { Zoological Science, 16(6), 993-1000 } \\
\text { https://doi.org/10.2108/2s.16.993 }\end{array}$ \\
\hline Issue Date & 1999-06 \\
\hline Doc URL & http://hdl.handle.net/2115/66620 \\
\hline Type & article \\
\hline File Information & zsj.16.993.pdf \\
\hline
\end{tabular}

Instructions for use 


\section{Phylogenetic Comparison of Endosymbionts with Their Host Ants Based on Molecular Evidence}

Author(s): Shinya Sameshima, Eisuke Hasegawa, Osamu Kitade, Nobuhiro Minaka, and Tadao Matsumoto

Source: Zoological Science, 16(6):993-1000.

Published By: Zoological Society of Japan

https://doi.org/10.2108/zsj.16.993

URL: http://www.bioone.org/doi/full/10.2108/zsj.16.993

BioOne (www.bioone.org) is a nonprofit, online aggregation of core research in the biological, ecological, and environmental sciences. BioOne provides a sustainable online platform for over 170 journals and books published by nonprofit societies, associations, museums, institutions, and presses.

Your use of this PDF, the BioOne Web site, and all posted and associated content indicates your acceptance of BioOne's Terms of Use, available at www.bioone.org/page/terms_of_use.

Usage of BioOne content is strictly limited to personal, educational, and non-commercial use. Commercial inquiries or rights and permissions requests should be directed to the individual publisher as copyright holder. 


\title{
Phylogenetic Comparison of Endosymbionts with Their Host Ants Based on Molecular Evidence
}

\author{
Shinya Sameshima ${ }^{1 *}$, Eisuke Hasegawa ${ }^{2}$, Osamu Kitade $^{3}$, Nobuhiro Minaka ${ }^{4}$ and \\ Tadao Matsumoto ${ }^{1}$ \\ ${ }^{1}$ Department of Biology, Graduate School of Arts and Sciences, University of Tokyo, Tokyo, Japan, \\ ${ }^{2}$ Department of Ecology and Systematics, Graduate School of Agriculture, \\ Hokkaido University, Sapporo, Japan, \\ ${ }^{3}$ Faculty of Science, Ibaraki University, Ibaraki, Japan, and \\ ${ }^{4}$ Laboratory of Statistics, Division of Information Analysis National Institute of \\ Agro-Environmental Sciences, Ibaraki, Japan
}

\begin{abstract}
Some Formicid ants have symbiotic intracellular bacteria in the epithelial cells of their midgut. These endosymbionts are believed to be derived from a common ancestor. A recent study revealed that endosymbionts of the ant genus Camponotus are closely related to Enterobacteriaceae, but their relationship to endosymbionts of other genera of ants is unknown. In this study, the nucleotide sequences of $16 \mathrm{~S}$ ribosomal RNA (rRNA) of endosymbionts and mitochondrial cytochrome oxidase subunit I (COI) of their host were determined in five genera of the subfamily Formicinae (Hymenoptera: Formicidae). Based on these molecular data, we constructed phylogenetic trees in order to characterize the systematic position of the symbionts and to estimate the relationship of symbionts and hosts. The analysis showed that the endosymbionts were all connected with the Enterobacteriaceae but did not constitute a monophylitic group, while the three genera belonging to the tribe Camponotini, the endosymbionts and their hosts made a clade. The topologies of these trees were identical for the most part. These results suggest that the endosymbionts of ants have plural origins, and that in the Camponotini, ancestral symbionts have coevolved with their host ants, which are so divergent to several genera as to construct one tribe.
\end{abstract}

\section{INTRODUCTION}

Many insects, across a wide taxonomic spectrum, contain non-parasitic intracellular microorganisms (Buchner, 1965). There are two kinds of such microorganisms. "Guest microorganisms," most of which have no distinguishable effects on the survival, growth, and fecundity of the hosts, are present in various types of host cells. Guest microorganisms have been recorded in the majority of insect orders. The other one, "Mycetocyte endosymbionts" are restricted to host insect cells characterized by particular morphology and location, termed "mycetocytes." Mycetocyte endosymbionts are usually obviously advantageous to their host (Douglas, 1989). They are mainly observed on seven orders of insects: widespread in Blattaria, Hemiptera, Anoplura and Coleoptera, and a few host taxa from Mallophaga, Diptera, and Hymenoptera.

In the Hymenoptera, one of the taxan carrying mycetocyte endosymbionts is ants, the family Formicidae. The endosymbionts of ants were first reported in Camponotus ligniperda

\footnotetext{
* Corresponding author: Tel. +81-3-5454-6652; FAX. +81-3-5454-4322.

E-mail: ss77216@mail.ecc.u-tokyo.ac.jp
}

and Formica fusca (Blochmann, 1892). Thus far, several genera in the subfamily Formicinae are known as hosts: eight genera (including Camponotus) in the tribe Camponotini, the genus Formica in the tribe Formicini, and the genus Plagiolepis in the tribe Plagiolepidini (Buchner, 1965; Jungen, 1968; Dasch et al., 1984). The tribe Camponotini is comprised of 14 genera, and mycetocyte symbiosis seems to be common among them (Dasch et al., 1984). In Formica, the presence of symbionts varies with the species, the colony and the individual (Jungen, 1968), whereas the situation for Plagiolepis is unclear. Endosymbionts are observed in the mycetocytes in the midgut of workers, queens, males, larvae and pupae. Ovaries of workers and queens also contain symbiotic bacteria. The symbionts are vertically transmitted from the ovary to the eggs of the next generation (Lilienstein, 1932; Buchner, 1965).

Some morphological differences are known between the mycetocyte symbiosis of the Camponotini and two other host genera. In the Camponotini, mycetocytes of the midgut are localized between epithelial cells and rest on the basal membrane, filled with Gram-negative and rod-shaped symbionts arranged in an orderly fashion (Lilienstein, 1932; Buchner, 1965). In the adult midgut, they are straight rods, $1 \mu \mathrm{m}$ wide and 5-15 $\mu \mathrm{m}$ long (Kolb, 1959). The symbionts lie freely in 
the cytoplasm (Dasch et al., 1984), like that of the tsetse fly Glossina (Reinhardet et al., 1972) and the weevil Sitophilus (Nardon and Grenier, 1988), whereas in most insects the symbionts are individually enclosed by a membrane originating from the host cell. In Formica and Plagiolepis, mycetocytes are not in the midgut epithelium but arranged in an unicellular layer behind the midgut (Lilienstein, 1932; Buchner, 1965). The symbionts are Gram-negative, rod-shaped, and free in the cytoplasm like those of Camponotini; however, the cell length is shorter, ranging from 3 to $4 \mu \mathrm{m}$.

The mycetocyte endosymbionts of insects are generally unculturable in vitro (Baumann and Moran, 1997) and are not amenable to traditional procedures for the taxonomy of microorganisms. Thus we have little information about the origin of the symbioses and the systematic relationships of the symbionts with other microorganisms. However, the development of polymerase chain reaction (PCR)-based techniques has provide a useful procedure for clarifying the phylogenetics of unculturable microorganisms. The nucleotide sequence data of the 16S rRNA gene provide the most useful information for the phylogeny reconstruction and systematic characterization (Carl, 1987). A number of insect endosymbionts have been the subject of molecular phylogenetic analyses and systematic characterization, such as the pea aphid (Unterman et al., 1989), whitefly (Clark et al., 1992) and tsetse fly (Beard et al., 1993, Askoy et al., 1995).

In ants, the systematic relationships of symbionts of the genus Camponotus were characterized based on the analy- sis of the 16S rRNA gene, revealing that endosymbionts of Camponotus belong to the gamma-subdivision of the Proteobacteria and are placed contiguous to the Enterobacteriaceae (Schröder et al., 1996). However, endosymbionts of the other taxa in the Formicinae were not included in that analysis. The origin of mycetocyte symbiosis of ants and the phylogeny among symbionts in each host taxon are thus still unclear. In this study, the nucleotide sequences of the endosymbionts' 16S rRNA gene were examined in 15 species belonging to Camponotus, Colobopsis, Polyrhachys, Formica, and Plagiolepis. A molecular phylogenetic analysis was carried out in order to characterize the systematic position of the symbionts among known prokaryotic microorganisms and to clarify the phylogeny among them.

\section{MATERIALS AND METHODS}

\section{Insect species}

The ant species investigated in this study are summarized in Table 1. The genus Colobopsis is often regarded as a subgenus of Camponotus. In this paper, it is treated as a separate genus. Oecophylla smaragdina was used as the outgroup in the phylogenetic analysis of the host ants. Based on a phylogenetical analysis of $\mathrm{COI}$ sequences, this genus is the most basal in the phylogenetic tree which contains 22 ant genera (Hasegawa, unpublished).

For Camponotus japonicus, Colobopsis nipponicus, Formica fusca and Plagiolepis pigmaea, the sample locations were not identical. A sample from a location $(H)$ was used for the sequencing of the COI gene of a host and (S) for the 16S rRNA gene of a symbiont. In ants, as compared with interspecific variation, the intraspecific varia-

Table 1. List of ants investigated in this study.

$\mathrm{H}$ : sampled for sequencing of host COI, S: for symbiont 16S rRNA

\begin{tabular}{|c|c|c|c|c|}
\hline \multirow{2}{*}{\multicolumn{2}{|c|}{ Species }} & \multirow{2}{*}{ Sampling sites } & \multicolumn{2}{|c|}{ GenBank accession numbers } \\
\hline & & & host COI & symbiont $16 \mathrm{~S}$ rRNA \\
\hline 1. & Camponotus japonicus & $\begin{array}{l}\text { Hachioji, Tokyo Met. Japan }(\mathrm{H}) \\
\text { Mequro, Tokyo Met. Japan (S) }\end{array}$ & AB019411 & AB018670 \\
\hline 2. & C. kiusiuensis & Meguro, Tokyo Met. Japan & AB019412 & AB018671 \\
\hline 3. & C. nawai & Okinawa island, Japan & AB019413 & AB018672 \\
\hline 4. & C. quadrinotatus & Meguro, Tokyo Met. Japan & AB019414 & AB018673 \\
\hline 5. & C. vagus & Firenze, Italy & AB019415 & AB018674 \\
\hline 6. & C. vitiosus & Meguro, Tokyo Met. Japan & AB019416 & AB018675 \\
\hline 7. & Colobopsis nipponicus & $\begin{array}{l}\text { Kamogawa, Chiba Pref. Japan (H) } \\
\text { Meguro, Tokyo Met. Japan (S) }\end{array}$ & AB019417 & AB018676 \\
\hline 8. & Colobopsis sp. & Okinawa island, Japan & AB019418 & AB018677 \\
\hline 9. & Formica fusca & $\begin{array}{l}\text { Puszcza, Poland }(\mathrm{H}) \\
\text { Firenze, Italy }(\mathrm{S})\end{array}$ & AB010925 & - \\
\hline 10. & F. lemani & Gotenba, Shizuoka Pref. Japan & AB019425 & AB018684 \\
\hline 11. & F. yessensis & Ishikari, Hokkaido Pref. Japan & AB010928 & - \\
\hline 12. & Plagiolepis manczshurica & Inchon, Korea & AB019423 & AB018682 \\
\hline 13. & Pl. pigmaea & $\begin{array}{l}\text { Sierra de Huetor, Spain }(\mathrm{H}) \\
\text { Firenze, Italy }(\mathrm{S})\end{array}$ & AB019414 & AB018683 \\
\hline 14. & Polyrhachis dives & Okinawa island, Japan & AB019419 & AB018678 \\
\hline 15. & P. hippomanes & Okinawa island, Japan & AB019420 & AB018679 \\
\hline 16. & P. lamellidens & Machida, Tokyo Met. Japan & AB019421 & AB018680 \\
\hline 17. & P. ypsilon & Bako, Sabah, Malaysia & AB019422 & AB018681 \\
\hline 18. & Cataglyphis rosenhaueri & Sierra Nevada, Spain & AB010933 & - \\
\hline 19. & Lasius spathepus & Kokubunji, Tokyo Met. Japan & AB007983 & - \\
\hline 20. & Polyergus rufescens & Sierra de Huetor, Spain & AB010931 & - \\
\hline 21. & Oecophylla smaragdina & Lambir, Salawak, Malaysia & AB019426 & - \\
\hline
\end{tabular}


tions are so small that sample locations do not affect the phylogeny reconstruction.

\section{DNA extraction}

The procedure used for the extraction of bacterial DNA was modified from Laird et al. (1991). The midguts and ovaries of ants were dissected and washed in $0.4 \% \mathrm{NaCl}$. The tissue sample was homogenized in a $1.5 \mathrm{ml}$ micro-centrifuge tube containing $500 \mu \mathrm{l}$ lysis buffer (100 mM Tris- $\mathrm{HCl}, 5 \mathrm{mM}$ EDTA, $0.2 \%$ SDS, $200 \mathrm{mM} \mathrm{NaCl}$ ). The mixture was frozen in liquid nitrogen and defrosted at $50^{\circ} \mathrm{C}$. Fifty $\mu \mathrm{g}$ of Proteinase $\mathrm{K}$ (Wako Chemicals) was added to the mixture, and incubated overnight at $55^{\circ} \mathrm{C}$. Then, $10 \mu \mathrm{g}$ of RNase A (Boehringer Mannheim) was added and incubated at $37^{\circ} \mathrm{C}$ for $30 \mathrm{~min}$. Following a series of phenol-chloroform and chloroform extraction, DNA was precipitated with an equal volume of isopropanol. Pelleted DNA was dissolved in $40 \mu \mathrm{l}$ TE buffer ( $10 \mathrm{mM}$ Tris- $\mathrm{HCl}, 1 \mathrm{mM}$ EDTA). Genomic DNA of the host was also extracted from a mesosoma of an individual ant by the same method, which was uesd as the templates for the amplification of the $\mathrm{COI}$ gene.

\section{Amplification and purification}

A partial 16S rRNA region was amplified by PCR (Saiki et al., 1988). The primer sequences used in this study are shown in Table 2. The PCR was performed with universal primers that were designed to amplify a fragment of 16 S rRNA of eubacteria approximately 570 base pair (bp) long (Lane et al., 1985). Reactions were performed in a GeneAmp 2400 thermal cycler (Perkin-Elmer) with the following conditions: 35 cycles of denaturation at $94^{\circ} \mathrm{C}$ for $30 \mathrm{sec}$, annealing at $54^{\circ} \mathrm{C}$ for $1 \mathrm{~min}$ and extension at $72^{\circ} \mathrm{C}$ for $2 \mathrm{~min}$, followed by an additional extension at $72^{\circ} \mathrm{C}, 1 \mathrm{~min}$. Final volume of the reaction mix was $40-\mu \mathrm{l}$ composed of $30 \mu \mathrm{l}$ of distilled water, $4 \mu \mathrm{l}$ of $10 x \mathrm{xCR}$ buffer (100 $\mathrm{mM}$ Tris- $\mathrm{HCl}$ [pH8.3], $500 \mathrm{mM} \mathrm{KCl}, 15 \mathrm{mM} \mathrm{MgCl}_{2}, 0.01 \%[\mathrm{w} / \mathrm{v}]$ gelatin, Takara), $4 \mu$ l of dNTP mix ( $1 \mathrm{mM}$ each of dATP, dGTP, dCTP and dTTP), $0.4 \mu$ leach of a pair of primers $(100 \mathrm{mM}), 0.7 \mathrm{U}$ of Taq polymerase (Takara TaKaRa Taq) and $1 \mu$ l of template DNA (10-200 ng). The PCR products were purified using Prep-A-Gene DNA Purification Kit (Bio Rad). The COI region was also amplified with PCR. Reactions were performed in the GeneAmp 2400 thermal cycler with the following conditions: 30 cycles of denaturation at $94^{\circ} \mathrm{C}$ for $1 \mathrm{~min}$, annealing at $45^{\circ} \mathrm{C}$ for $1 \mathrm{~min}$ and extension at $60^{\circ} \mathrm{C}$ for $3 \mathrm{~min}$, followed by an additional extension at $60^{\circ} \mathrm{C}$ for $1 \mathrm{~min}$. The purification of the PCR products was performed by the same procedure. Purified products of the $\mathrm{COI}$ gene were subjected to the direct sequencing.

Table 2. Primer sequences used for amplification of bacterial $16 \mathrm{~S}$ rRNA gene and COI gene.

\begin{tabular}{ccl}
\hline region & name & \multicolumn{1}{c}{ sequence $\left(5^{\prime}\right.$-3') } \\
\hline 16S rRNA & 16S F-2 & AACAAGATTAGATACCCTGGG \\
& UNI 1400 R & ACGGGCGGTGTGTA(AG)CAA \\
COI & COI 1-3 & ATAATTTTTTTATAGTTATACC \\
& COI 2-1 & CTTTATCAACATTTATTTTGATTTTT \\
& COI 2-3 & GAAGTTTATATTTTAATTTACC \\
& COI 2-2 & ACTCCAATAAATATTATAATAAATTGA \\
& COI 2-4 & TCCTAAAAAATGTTGAGGAAA \\
\hline
\end{tabular}

\section{Cloning of 165 rRNA}

Purified products were ligated into pUC18 vector with a SureClone ligation kit (Pharmacia), and competent cells of $E$. coli (DH5) were transformed. They were inoculated on the LB ager plates containing ampiciline $(50 \mathrm{mg} / \mathrm{ml})$ and cultivated over night at $37^{\circ} \mathrm{C}$. Single colonies were inoculated into $3 \mu$ of LB medium containing ampiciline (50 $\mathrm{mg} / \mathrm{ml}$ ), followed by the $20 \mathrm{hr}$ of liquid cultivation at $37^{\circ} \mathrm{C}$. Mini-preparation of vecter DNA was perforned with boiling method. Length of insert in vecter DNA was checked with EcoRI-HindIII double diges- tion. Clones with appropriate inserts were purified with a series of phenol/chloroform and diethylether extraction, after the digestion of RNA with RNase A. Purified DNA was dissolved in $10 \mu \mathrm{l}$ distilled water and used as the template for the sequencing reaction.

\section{Nucleotide sequencing}

Sequencing reactions were performed [on the GeneAmp 2400 thermal cycler] with the dideoxy-nucleotide cycle sequencing procedure using a Dye-Primer Cycle Sequencing Kit for the 16S rRNA clone and a Dye-Terminator Cycle Sequencing Kit (Perkin-Elmer) for the purified PCR products. Electrophoresis and data collection were performed using an automatic DNA sequencer (Perkin-Elmer model 373S) with $5.5 \%$ polyacrylamide gels (Super Reading DNA Sequence Solution, Toyobo).

\section{Phylogenetic analysis}

Sequences were analyzed by the neighbor-joining method (Saitou and Nei, 1987). The alignments and tree constructions were performed with the Clustal W program package (Thompson et al., 1994). Gap positions were included in the analysis. The numbers of the nucleotide substitutions were estimated according to Kimura's twoparameter method (Kimura, 1980). Bootstrap confidence intervals (Felsenstein, 1985) on each branching pattern were calculated from 1,000 resamplings. Parsimony analysis was also carried out with the PAUP 3.1.1 software program package (Swofford, 1993), with the heuristic search option with 100 random addition replicates. Gaps were treated as new states. Relative support for different nodes was assessed using 1,000 bootstrap replicates (Felsenstein, 1985) with 5 random addition sequence replicates for each bootstrap replicate. The following sequences of bacterial 16S rRNA were obtained from the GenBank database for the phylogenetic analysis of the endosymbionts; Escherichia coli (V00348), Ewingella americana (X88848), Glossina pallidipes S-endosymbiont (M99060), Melaphis rhois Pendosymbiont (M63255), Proteus vulgaris (X07652), Salmonella sofia (X80677), Schlectendalia chinensis P-endosymbiont (Z19056), Yersinia pestis (Z75317) and Xenorhabdus beddingii (D78006). Haemohilus ducreyi (M63900), H. influenzae (Z22806), Pasteurella haemolytica (U57072) and P. trehalosi (U57074), classified into the Pasteurellaceae, were set as the outgroup. The nucleotide sequence data of the 16S rRNA of the symbionts of the ants and the COI of the hosts reported in this paper will appear in the DDBJ/EMBL/GenBank nucleotide sequence databases with the accession numbers listed in Table 1.

\section{RESULTS}

\section{Identity of the clones of the 16S rRNA gene}

Preliminary sequencing of eight clones of the gene encoding the 16S rRNA derived from the midgut of Camponotus vitiosus, and of six clones derived from the ovaries showed that 11 of the sequences were identical, and that the other three clones differed by only 1 or 2 bps. It is likely that these small differences were due to ether reproduction errors of the Taq polymerase or point mutations. Therefore we concluded that all of the clones originated from the same endosymbiont. Eight clones from the midgut and six clones from the ovaries of Plagiolepis pigmaea were also sequenced; all 14 clones were identical. The PCR products of both $C$. vitiosus and $P$. pigmaea were also sequenced directly and the sequences were identical to those of the majority of the clones. Therefore, direct sequencing was used to identify the endosymbionts of the rest of the ant species. The length of the 16S rRNA gene analyzed in this study ranged from 567 to 575 bps. 
Insertions of 5 bps in $C$. vitiosus and 4 bps in $C$. nawai were present at the same position. This insertion region was excluded from the analysis.
Phylogenetic analysis of the endosymbionts

Homology searches of the GenBank database showed that the 16SrRNA gene of the endosymbionts were more than $90 \%$ homologous to those of the Enterobacteriaceae. Pre-

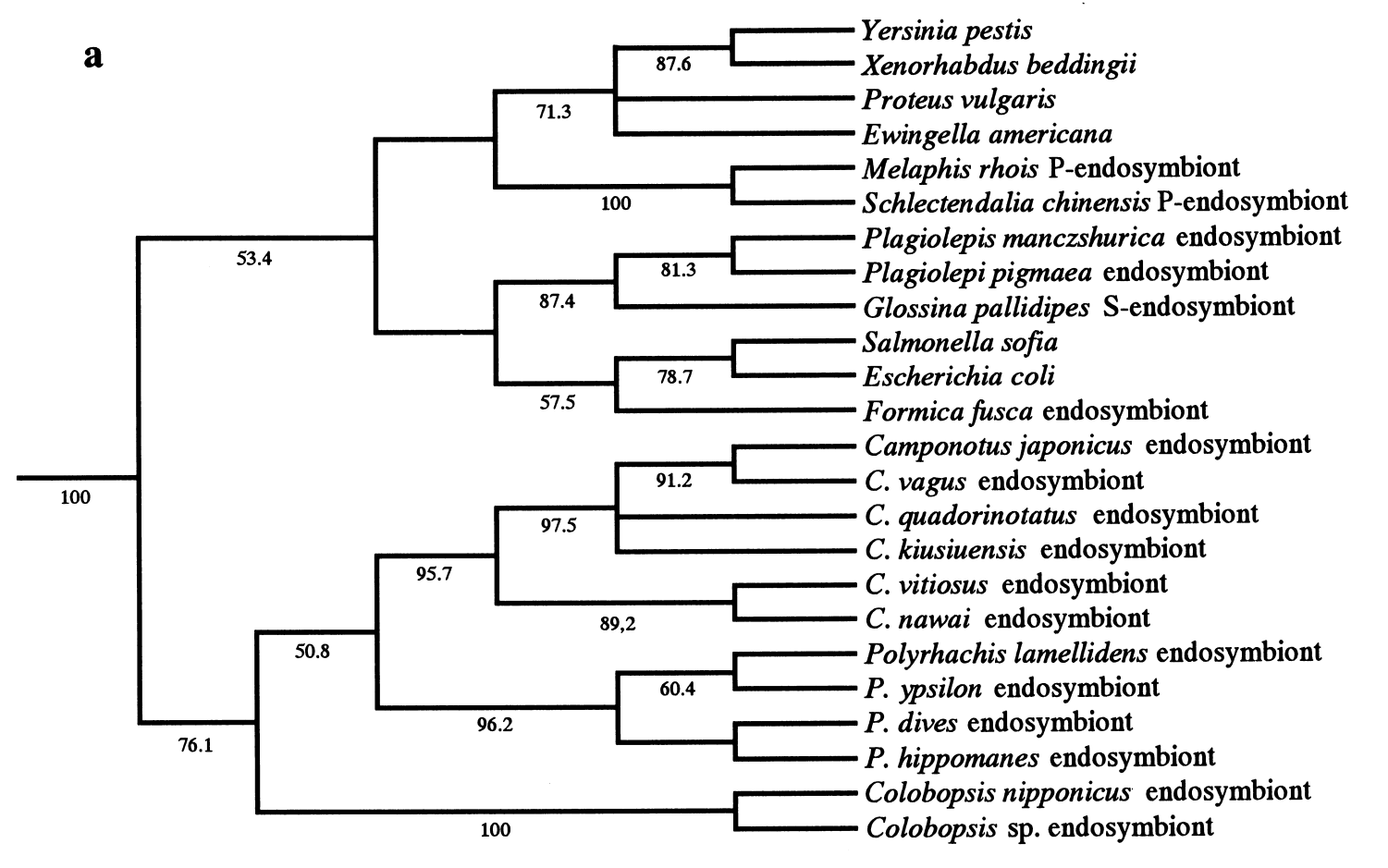

\rfloor $\mathrm{Pla}$
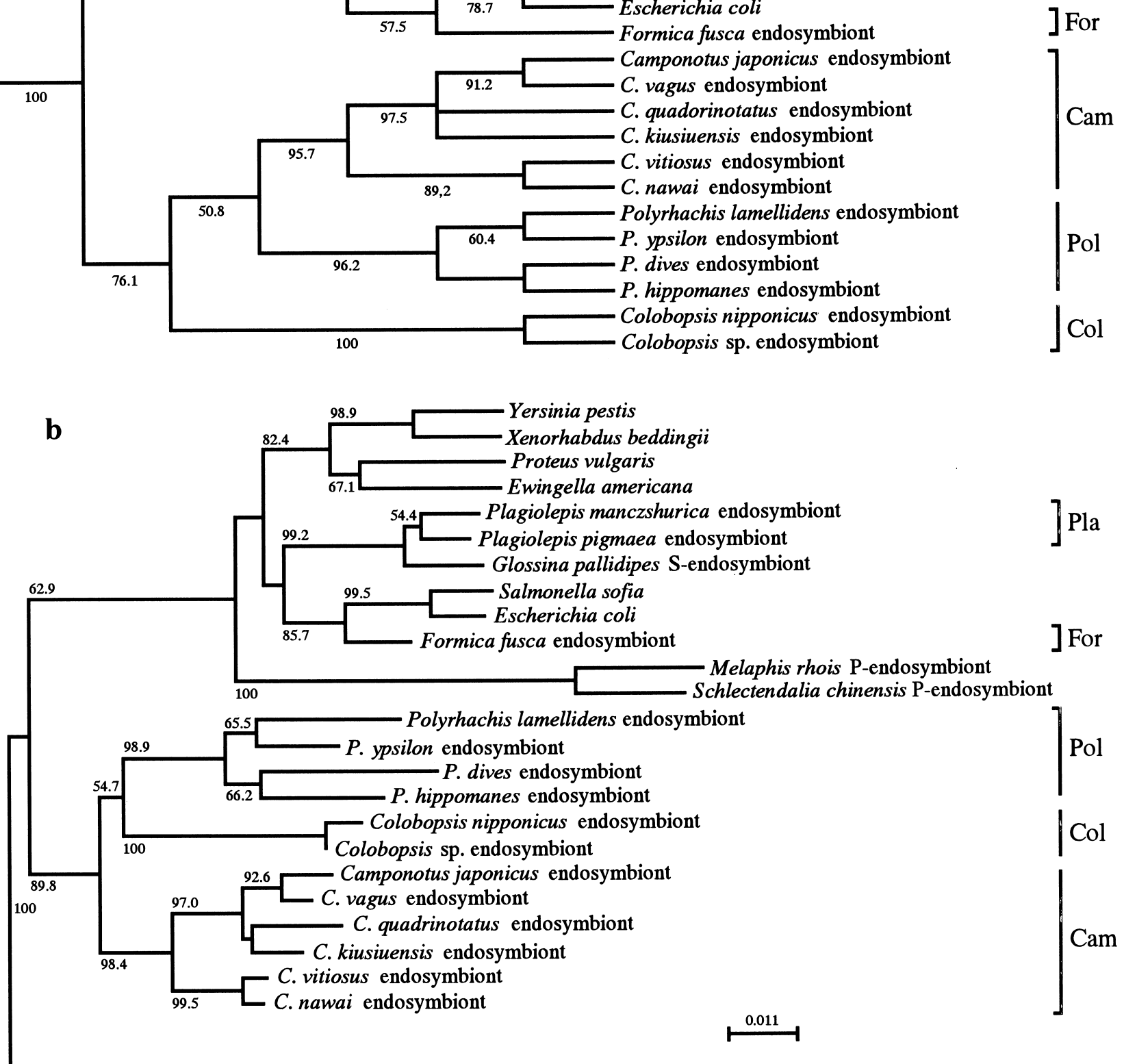

Fig. 1. Phylogenetic trees of the endosymbionts of ants based on $570 \mathrm{bp}$ of the $16 \mathrm{~S}$ rRNA gene sequence. a: Strict consensus tree of parsimony analysis. Numbers on the branches indicate the percentage of 1,000 bootstrap replicates. b: Bootstrapped tree of neighbor-joining analysis. Numbers on the branches indicate the percentage of 1,000 bootstrap replicates. Cam; Camponotus, Col; Colobopsis, Pol; Polyrhachis, For; Formica, Pla; Plagiorepis. 
liminary phylogenetic analysis of eight groups of the gamma subdivision of the Enterobacteriaceae (Alteromonadaceae, Enterobacteriase, Methylococcaceae, Halomonadaceae, Pasteurellaceae, Pseudomonas, Vibrionaceae, Xanthomonas) rooted with the Alcaligenaceae and the Neisseriaceae classified into the beta-subdivision (Olsen et al., 1994) showed that the endosymbionts of the Formicinae form a clade with the Enterobacteriase. Therefore, four species in the Pasteurellaceae were assigned to the outgroup in the following analysis (data not shown). The species names and the accession numbers of the outgroup are described in the materials and methods section.

Trees were constructed using the 570-bp 16S rRNA gene sequences by the maximum parsimony (MP) method (Fig. 1a) and by the neighbor-joining (NJ) method (Fig. 1b). The parsimony analysis resulted in four most parsimonious trees with 454 steps, and a strict consensus tree. The results indicated that the endosymbionts of five genera of the Formicinae were the Enterobacteriaceae or were closely related to the Enterobacteriaceae.

The endosymbionts of the ants did not constitute a monophyletic group. The endosymbionts of Plagiolepis spp. and Formica fusca were both in the clade of the Enterobacteriaceae. The endosymbionts of Plagiolepis spp. were the closest relatives of the S-endosymbiont of the tsetse fly, Glossina pallidipes. The endosymbionts of Formica fusca formed a monophyletic group with Salmonera and Escherichia. The endosymbionts of three host genera in the Camponotini (Camponotus, Colobopsis and Polyrhachys) constituted a single clade, which was the sister group of the Enterobacteriaceae. The monophyly of the clade was supported by relatively high bootstrap values (MP, 76.1\%; and NJ, 89.8\%). In this clade, the endosymbionts of each host genera formed monophyletic groups, supported by bootstrap values of more
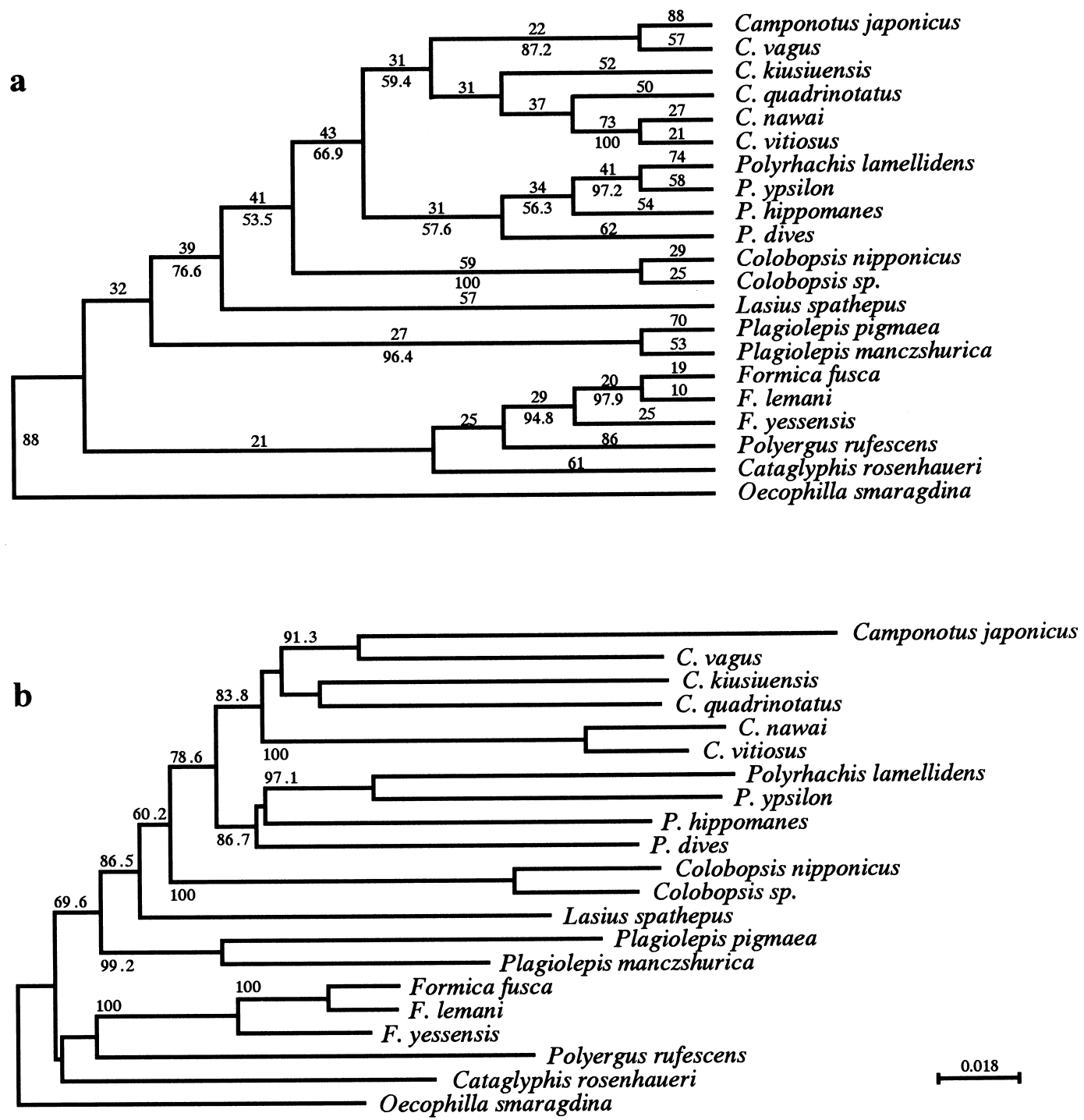

Fig. 2. Phylogenetic trees of the host ants based on $974 \mathrm{bp}$ of the COI gene sequence. a: The single most parsimonious tree of the parsimony analysis is shown. The numbers above the branches indicate the branch length, and the numbers below the percentage of 1,000 bootstrap replicates. b: Bootstrapped tree of neighbor-joining analysis. Numbers on the branches indicate the percentage of 1,000 bootstrap replicates. 
than $90 \%$. The MP tree indicated that the relationships of the symbionts of the three genera in the Camponotini were (Colobopsis + (Polyrhachys + Camponotus $))$, whereas the NJ tree supported ((Colobopsis + Polyrhachys) + Camponotus $)$, however statistical support was not significant.

\section{The phylogeny of the host ants}

The COI gene was sequenced in 21 species in Formicinae including five genera and 15 species of hosts. The length of the sequence used for the analysis in this study was 974 bps.

The parsimony analysis of the ant species resulted in a single most-parsimonious tree with 1702 steps (Fig. 2a). The members of each of the five host genera formed clades. The monophyly of each host genus was also shown by NJ analysis (Fig. 2b). In both analyses, the five host genera did not form a monophyletic group, although three of these genera, the members of the Camponotini, were monophyletic. These relations reflected those between the endosymbiont groups, however the branching patterns of the endosymbionts were not the same as those of the hosts. The analysis of the hosts showed that Formica was in the basal position and the Camponotini was at the apex.

Our analyses by the MP and NJ methods both resulted in the same topology for the three genera of the Camponotini with bootstrap values of more than $50 \%$ in each case: (Colobopsis + (Polyrhachys + Camponotus $))$. Three species of Formica formed a monophyletic group with Polyergus rufescens and Cataglyphis rosenhaueri; they all belong to the Formicini, but the relationships among the three genera were supported by less than $50 \%$ of the bootstrap replicates.

\section{DISCUSSION}

It is usually impossible to extract enough morphological characters for phylogenetic analysis from prokaryotic microorganisms; ribosomal genes provide the most useful information for phylogeny reconstruction and systematic characterization of microorganisms, and are the most commonly used molecular markers for phylogenetics (Carl, 1987). However, careful interpretation is necessary to align the sequences, because insertions and deletions are more frequent than in protein-coding genes. In this study, 5 bps of insertions found in Camponotus vitiosus and 4 bps in $C$. nawai were excluded from the analysis. They seemed to originate from a single insertion event, which took place on a common ancestor of the subgenus Myrmamblys. Other deletions, which were all single base deletions, were included in the analysis to maximize the available information. Gap-exclusive analysis was also performed and gave the same topologies as gap-inclusive analysis both by the MP and NJ methods (data not shown).

To establish the phylogenetic tree of the host ants, we choose to study the COI gene because it has excellent properties as a molecular marker; it is the largest protein-coding mitochondrial gene and detailed information is available about its protein product, a respiratory enzyme, including variability of each domain (Lunt et al., 1995). These features enable us to perform multiple factor analysis based on information about codon positions or domains. We estimated the saturation of nucleotide substitutions to plot the number of transitions and transversions against the uncorrected genetic distance for each codon position (Reo et al., 1997) and we found that saturation of transitions may have occurred at the third codon. Therefore, weighted parsimony analysis was performed using four weighting schemes: weighting transversions 2, 4, and 8 times of transitions at the third codon and excluding transitions at the third codon (Reo et al., 1997). However, the topologies we obtained using these schemes were all identical to that of the non-weighted MP tree (data not shown).

It has been proposed that the endosymbionts of the Formicinae have a common origin for two reasons. First, the distribution of the endosymbionts is restricted to the subfamily Formicinae. Second, the morphology and the pattern of transmission of the endosymbionts is similar among the Formicinae (Jungen, 1968; Dasch et al., 1984). However, the molecular phylogeny obtained in this study did not support this hypothesis of a common origin for both the endosymbionts and the hosts. Instead, the results of the present study suggested that the endosymbionts have been independently acquired by the Formicinae at least three times: by the common ancestor of the Camponotini, by the ancestor of Plagiolepis, and by the ancestor of Formica.

Within the Camponotini, the phylogeny of the endosymbionts showed strong, if not perfect, congruence with that of the hosts. In our topological comparison among the symbionts and the hosts within the Camponotini (Fig. 3) clades supported by bootstrap values of less than $50 \%$ were treated as polytomy. Camponotus, Polyrhachys and Colobopsis formed a single clade in all cases, and the topology (Colobopsis + (Polyrhachys + Camponotus)) was supported in three cases (Fig. 3a, 3c and 3d). Within Camponotus, the branching patterns of four analyses had nearly identical topologies. The situation was the same within the genus Polyrhachys with the exception of $P$. dives, which formed a subcluster with $P$. hippomanes in the analysis of the symbionts by the NJ method (Fig. 3b), although it was in the basal position of the clade of Polyrhachys in the analysis of the hosts by the MP method (Fig. 3c). Dasch et al. (1984) studied the endosymbionts of 8 of 14 known genera of the Camponotini and concluded that mycetocyte symbiosis is common in this tribe. We suggest that a single bacterial infection occurred in a common ancestor of the Camponotini, followed by co-speciation of the hosts and the endosymbionts. Improved data matching may be seen in future analyses after more data has been collected, in particular on Colobopsis.

Schröder et al. (1996) compared the 16S rRNA gene of the endosymbionts of four Camponotus spp. with the endosymbionts of aphids (Buchnera), P-endosymbionts of the tsetse fly and other members of the Enterobacteriaceae. Their results indicated that the Camponotus symbionts form a clade ((Camponotus + tsetse fly P-symbionts) + aphid) that is adjacent to the other members of Enterobacteriaceae. However, we obtained a different result: the endosymbionts of 

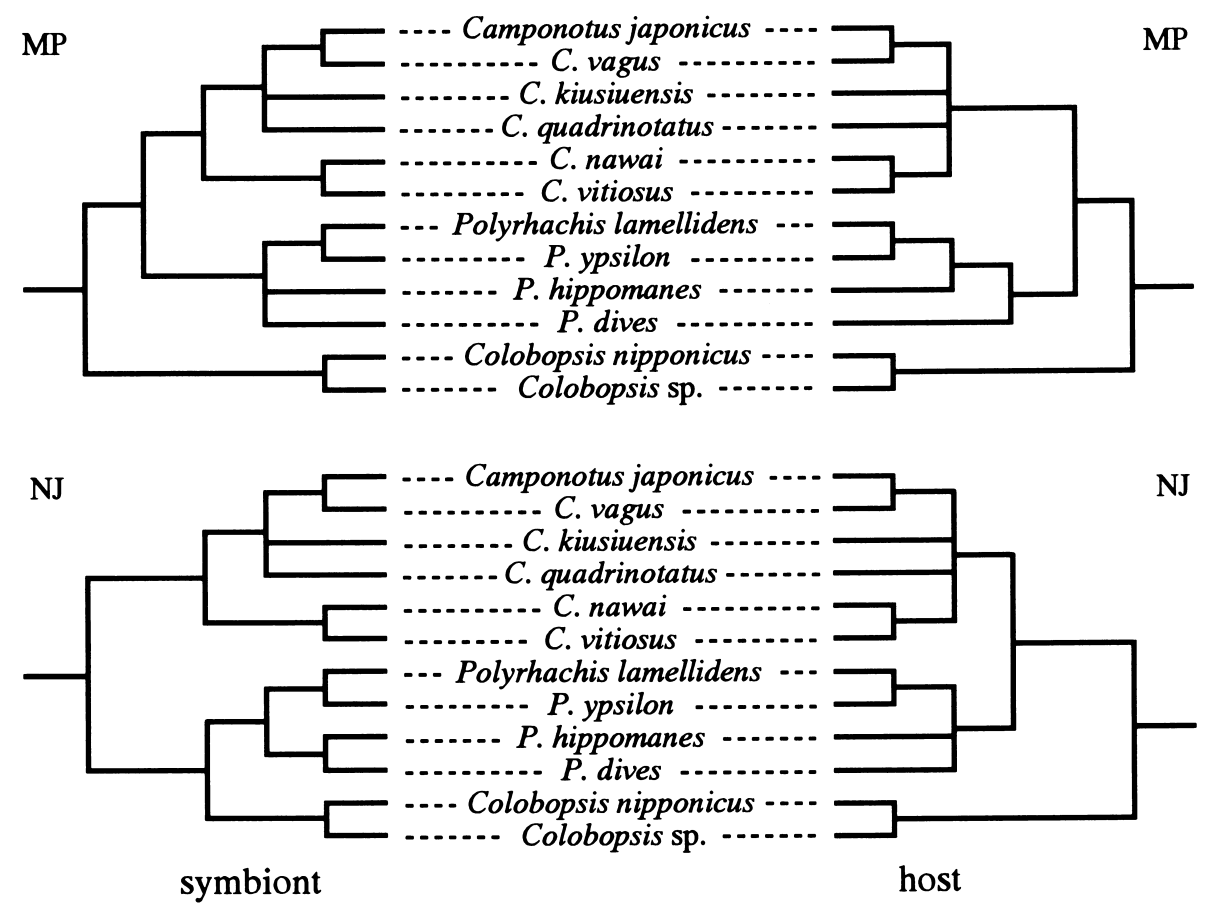

Fig. 3. Topological comparison between the symbionts and the hosts within the Camponotini. a, c: MP method; b, d: NJ method

Camponotus formed a clade with those of Colobopsis and Polyrhachis, and this clade was adjacent to the cluster of the Enterobacteriaceae, that contained Buchnera. The bootstrap values that supported this clade as a sister clade of the Enterobacteriaceae were low (54.3\% in MP, and $62.9 \%$ in $\mathrm{NJ}$ ), however the clade consisting of the symbionts of Camponotus, tsetse fly and aphid was not supported statistically (Schröder et al. 1996). The relationships among the endosymbionts of these insects, in either case, is not certain.

Two taxonomic treatments have been proposed for "Colobopsis"; an independent genus (Brown, 1973; Sneling, 1981; Hölldobler and Wilson, 1990) and a subgenus in the genus Camponotus (Bolton, 1996). The molecular phylogeny we present here supported the former viewpoint. Our result reflected the current subgeneric classification of the genus Camponotus and Polyrhachis (Hung, 1967; Bolton, 1996). The species $C$. japonicus and $C$. vagus, classified into the subgenus Camponotus, formed the subcluster (Figs. 1 and 2). Similarly the following species formed subclusters; $C$. vitiosus and $C$. nawai, into the subgenus Myrmamblys, $P$. lamellidens and $P$. ypsilon, into the subgenus Polyrhachis.

The presence of mycetocyte endosymbionts in Formicinae has not been surveyed comprehensively. Thus, new ant species that possess endosymbionts may be discovered in other genera or subfamilies. In the case of the genus Formica, endosymbiosis has been reported for only a small fraction of the known species (Jungen, 1968). Prior to this study, mycetocyte symbionts were preliminarily surveyed in several Formica species ( $F$. japonica, F. lemani, F. yessensis) in Japan. However no mycetocytes were found in these species. Jungen (1968) reported that the infection rate by endosymbionts in several colonies of Formica lemani was not $100 \%$ and that some colonies lack the symbionts. Considering these circumstances, more data is needed to clarify the biology of the endosymbionts of Formica. Phylogenetic analyses of the symbionts in other genera in the Formicini and in the Plagiolepidini will also be indispensable to establishing a detailed scenario of the establishment of the symbiosis.

Little is known about the biological relationships between ants and their endosymbionts, although many mycetocyte symbionts are known to have nutritional interactions with their hosts (Noggi, 1981; Cochran, 1985; Lai, 1994). It seems suggestive that the P-endosymbionts of the tsetse flies and aphids, which provide the host with essential nutrients, are related to the endosymbionts of the Formicinae. Although Smith (1944) discussed the relation between nutritional condition and infection by endosymbionts in Camponotus, there has been no experimental study of the contribution of endosymbionts to growth or survival of host ants. To understand the functions and biological significance of the endosymbionts of ants, experimental investigations, such as the removal of the symbionts from their hosts and feeding experiments, are essential. Detailed information regarding the phylogeny of the endosymbionts and their hosts should be useful for comparative studies of the relationships among various ant symbioses, and of the metabolism of the symbionts and their free-living relatives.

\section{ACKNOWLEDGMENTS}

We express our great gratitude to Dr. M. Terayama for identification of some of the ant species. Thanks are also due to Prof. M. Sasaki, Mr. H. Takamine for their valuable comments and help in sampling the ants. We also thank Drs. S. Yamane, A. Tinaut, W. Czechowski, and K. Tsuji for sample collection. This study was supported by a 
Grant in Aid for the Scientific Reserch (No. 07454211, 10440231) from the Ministry of Education, Science, Sports and Culture of Japan.

\section{REFERENCES}

Aksoy S, Pourhosseini AA, Chow A (1995) Mycetoma endosymbionts of tsetse flies constitute a distinct lineage related to Enterobacteriaceae. Insect Mol Biol 4: 15-22

Baumann P, Moran NA (1997) Non-cultivable microorganisms from symbiotic associations of insects and other hosts. Antonie van Leeuwenhoek 72: 39-48

Beard CB, O'Neill SL, Mason PW, Mandelco L, Woese CR, Tesh RB, Richards FF, Aksoy S (1993) Genetic transformation and phylogeny of bacterial symbionts from tsetse. Insect Mol Biol 1: 123131

Blochmann F (1892) Über das Vorkommen bakterienahnlicher Gebilden in den Geweben und Eiern verschiedener Insekten. Zbl Bakteriol 11: 234-240

Bolton B (1996) A new general catalogue of the ants of the world. Harvard Univ Press

Brown Jr WL (1973) A comparison of the Hylean and Congo-west african rain forest ant faunas. In "Toropical forest ecosystems in Africa and Sauth America: A comparative review", Ed by Meggers BJ, Ayensu ES, Duckworth WD, Smithsonian Institution Press, pp 161-185

Buchner P (1965) Endosymbiosis of animals with plant microorganisms. Interscience Publishers

Carl RW (1987) Bacterial evolution. Microbiol Rev 51: 221-271

Clark MA, Baumann L, Munson MA, Baumann P, Cambell BC, Duffus JM, Osbone LS, Moran A (1992) The eubacterial endosymbionts of whiteflies (Homoptera, Aleyrodoidae) constitute a lineage distinct from the endosymbionts of aphids and mealbugs. Cur Microbiol 25: 119-123

Cochran RA (1985) Nitrogen excretion in cockroaches. Ann Rev Entomol 30: 29-49

Dasch GA, Weiss E, Chang KP (1984) Endosymbionts of insects. In "Bergey's Manual of Systematic Bacteriology vol. 1", Ed by Krieg NR, Williams \& Williams, pp 881-883

Douglas AE (1989) Mycetocyte symbiosis in insects. Biol Rev 64: 409-434

Felsenstein J (1985) Confidence limits on phylogenies: an approach using the bootstrap. Evolution 39: 783-791

Holldobler B, Wilson EO (1990) The ants. The Belknap press of Harvard Univ press

Hung ACF (1967) A revision of the ant genus Polyrhachis at the subgeneric level (Hymenoptera: Formicidae). Trans Am Entomol Soc 93: 395-421

Jnngen H (1968) Endosymbionten bei Ameisen. Insects Soc 15: $227-$ 232

Kimura M (1980) A simple method for estimating evolutionary rates of base substitutions through comparative studies of nucleotide sequence. J Mol Evol 16: 111-120

Kolb G (1959) Untersuchngen uber die Kernverhaltniss und morphologischen Eigenschaften symbiontischer Mikroorganismen bei verschiedenen Insecten. Zei Morphol Ökol Tie 48: $1-71$

Lai C-Y, Baumann L, Baumann P (1994) Amplification of trpEg: adaptation of to an endosymbiotic association with aphids. Pro Nat Aca Sci USA 91: 3819-3823
Laird PW, Zijderveld A, Linders K, Rudnicki MA, Jeanisch R, Berns A (1991) Simplified mammalian DNA isolation procedure. Nuc Aci Res 19: 42-93

Lane DJ, Pace B, Olsen GJ, Stahl DA, Soign ML, Pace NR (1985) Rapid determination of $16 S$ ribosomal RNA sequences for phylogenetic analysis. Proc Nate Acad Sci USA 82: 6955-6959

Lilienstein M (1932) Beitrage zur Bacteriensymbiose der Ameisen. Zei Morphol Ökol Tie 26: 110-134

Lunt DH, Zhang D-X, Szymura JM, Hewitt GM (1995) The insect cytochrome oxidase I gene: evolutionary patterns and conserved primers for phylogenetic studies. Insect Mol: Biol 5: 153-165

Nardon P, Grenier AM (1988) Genetical and biochemical interactions between the host and its endcytobiontes in the weevils Sitophilus (Coleoptera, Curculionidae) and other related species. In "Cell to Cell Signals in Plant, Animal and Microbial Symbiosis ", Ed by Scannerini S, Smith CD, Bonfante-Fasolo P, Gianinazzi-Persom V, Springer Berlin, pp 255-270

Noggi G (1981) Significance of symbionts for the maintenance of an optimalnutritional state of successful reproduction in hematophagous arthropods. Parasitology 82: 299-304

Olsen GJ, Woese CR, Overbeek R (1994) The winds of (evolutionaly) change: breathing new life into microbiology J Bacteriol 176: 16

Reinhardet C, Steiger R, Hecker H (1972) Ultrastructual study of the midgut mycetome-bacteroids of the tsetse flies Glossina morsitans, G. fuscipes and G. brevipalpis. Act Tro 29: 280-288

Reo KJ, Conkel D, Lydeard C (1997) Molecular systematics of middle american cichlid fishes and the evolution of trophic-types in 'Cichlasoma (amphilophus)' and 'C. (thororichthys)' Mol Phyl Evol 7: 366-376

Saiki RK, Gelfand DH, Stoffel S, Schart SJ, Higuchi R, Horn GT, Mullis KB, Erlich HA (1988) Primer-directed enzymatic amplification of DNA with a thermostable DNA polymerase. Science 239: 487

Saitou N, Nei M (1987) The neighbor-joining method: a new method for reconstructing phylogenetic trees. Mol Biol Evol 4: 406-425

Schröder D, Deppisch H, Obermayer M, Krohne G, Stackebrandt E, Holldobler B, Geobel W Gross R (1996) Intracellular endosymbiotic bacteria of Camponotus species (carpenter ants): systematics, evolution and ultrastructural characterization. Mol Microbiol 21: 479-489

Smith F (1944) Nutritional requirements of Camponotus ants. Ann Entomol Soc Am 34: 401-408

Snelling RR (1981) Systematics of social Hymenoptera. In "Social insect II", Ed by Hermann HR, Academic Press, pp 370-453

Swofford DL (1993) PAUP: phylogenetic analysis using parsimony, Ver. 3.1.1. Smithsonian Institution, Washington, D. C.

Thompson JD, Higgins DG, Gibson TJ (1994) Clustal W: improving the sensitivity of progressive multiple sequence alignment through sequence weighting, positions-specific gap penalties and weight matrix choice. Nuc Aci Res 22: 4673-4680

Unterman BM, Baumann P, Mclean DL (1989) Pea aphid symbionts relationships established by analysis of $16 \mathrm{~S}$ rRNAs. J Bacteriol 171: 2970-2974

(Received December 10, 1998 / Accepted July 30, 1999) 